\title{
PHISICAL FUNCTION (MOTOR ACTIVITY) PADA PASIEN KRITIS DENGAN SEDATION DI INTENSIVE CARE UNIT
}

\author{
Heru Suwardianto*, Awal Prasetyo**, Reni Sulung Utami** \\ *Mahasiswa Prodi Magister Keperawatan Kepeminatan Keperawatan Dewasa \\ Konsentrasi Keperawatan Kritis Fakultas Kedokteran \\ Universitas Diponegoro Semarang \\ *Prodi DIII Keperawatan STIKES RS Baptis Kediri \\ Jl. Mayjend Panjaitan No. 3B Kota Kediri, Jawa Timur, Indonesia \\ ** Fakultas Kedokteran Universitas Diponegoro \\ Jl. Prof. Soedarto, Tembalang, Kota Semarang, Jawa Tengah, Indonesia \\ Email: herusuwardianto@gmail.com
}

\begin{abstract}
Introduction: Critical patients are patients who potentially get reversible dysfunction in one or more life-threatening organs and require they require care in the Intensive Care Unit (ICU). Method: The objective of this research is to analyze the physical functiontardive dyskinesia on critical patients with sedation in ICU. The design of this research is crossectional. The population is all critical patients in ICU Baptist Hospital Kediri. The sample is 41 respondents based on the inclusion and exclusion criteria in the total sampling. The independent variable is giving the sedation and the dependent variable is physical function-tardive dyskinesia. The data was collected using observation sheets. Result: The result shows that giving a sedation can decrease the physical function in the form of motor activity; response of noxious stimuli (7.3\%), response to touch or calling name $(19,5 \%)$ and the incresing score of agitation and co-operative (4.9\%). Symptoms of tardive dyskinesia increased after sedation in the form of tongue prostrusion (4.9\%), lip smacking puckering and pursing (2.4\%), and rapid movements of the arms and legs. Administration of sedation in the first 24-hour ICU patient affects the physical function of the critical patients $(\mathrm{p}=0.005)$. Conclusion: Giving sedation affects the change of patiens' physical funcion. Therefore, prevention on the effects of sedation and treatment during ICU is needed in order to avoid a decrease in the physical function of critical patients.
\end{abstract}

Keyword: physical function, tardive dyskinesia, sedation, critical patient, ICU

\section{PENDAHULUAN}

Pasien kritis merupakan keadaan yang berpotensi terjadinya disfungsi reversible pada salah satu atau lebih organ yang mengancam kehidupan dan memerlukan perawatan di Intensive Care Unit (ICU) (Ireland, 2011; AACN, 2016). Pasien kritis di ICU prevalensinya terus meningkat setiap tahunnya. World Health Organization (WHO) tahun 2016 melaporkan bahwa kematian akibat penyakit kritis hingga kronik di dunia meningkat sebanyak 1,1 - 7,4 juta orang dan terdapat 9,8-24,6 pasien sakit kritis dan dirawat di ICU per 100.000 penduduk (Garland et al., 2013). Pasien post ICU memiliki berbagai potensi masalah kesehatan akibat perawatan sebelumnya. Masalah post ICU biasa disebut dengan post intensive care syndrome (PICS). Post Intensive Care Syndrome merupakan masalah kesehatan yang muncul dan menetap dalam jangka waktu yang lama setelah pasien keluar dari ICU dan merupakan masalah keperawatan yang sangat penting untuk segera diselesaikan 
(Davidson et al., 2013). Post Intensive Care Syndrome merupakan kumpulan dari tiga gejala masalah atau gangguan berupa gambaran memburuknya status kelemahan fungsi fisik, kognitif, dan kecemasan (kesehatan mental) selama sakit kritis dan setelah pasien keluar dari ICU (Needham et al., 2012). Pasien kritis berhubungan langsung pada ketidaknyamanan yang memberikan efek non-cooperative, pasien akan mendiskripsikan nyeri dengan berbagai manifestasi secara verbal ataupun nonverbal. Pasien kritis yang dirawat di ruang intensif dengan ketidaknyamanan akan mendapatkan terapi sedasi. Pasien kritis mengalami keadaan sedasi dikarenakan oleh penatalaksanaan medis yang dilakukan oleh tenaga kesehatan di perawatan intensif. Pemberian opioid untuk mengurangi respon sakit, nyeri, kegelisahan, ataupun gerak involunter karena patologis penyakit sangat diperlukan. Sedasi berupa opioid dapat bereflek kepada keadaan kondisi fungsifungsi ditubuh dan mengalami depresi sistem saraf pusat. Sleep Deprivation merupakan hasil dari hasil agitasi-sedasi. Manajemen sedasi dapat dapat memberikan efek samping yaitu sedasi dan faktor resikonya adalah ederly analgesic dan sedative (Carlson, 2009). Depresi pernapasan dapat terjadi sebagai efek yang sering muncul, perawat harus mempu mengidentifikasikan dan menganalisa dengan baik keadaan agitasi dari sedasi yang diberikan. Efek-efek yang dapat dilihat dapat berupa respon pasien secara verbal maupun nonverbal. Jika perawat tidak dapat mengetahui dan menganalisa hasil akhir dari efek sedasi dan tindakan yang harus dilakukan maka keadaan pasien dapat bertambah buruk karena kita tidak dapat dinilai secara cepat oleh perawat, karena keadaan kritis pasien perlu suatu penilaian yang cepat dan tepat untuk dilakukan.

Pasien kritis selama di ICU akan kehilangan $20 \%$ volume otot, dan $70 \%$ protein selama 1 minggu dirawat di ICU.
Hasil studi didapatkan juga sebanyak 476,862 pasien $(60 \%-80 \%$ dari total pasien post ICU) dengan $30 \%$ diantaranya tidak dapat kembali bekerja (nonproduktif) karena kehilangan kekuatan otot sebanyak $1 \%-2 \%$ setiap harinya setelah pasien keluar dari ICU. Pasien dengan kehilangan fungsi otot dapat dilihat dari kondisi motor activity dan reaksi dari proses sedasi. Penurunan fungsi kognitif berhubungan dengan penurunan metabolisme oksidatif otak yang menyebabkan perubahan neurotransmiter di daerah prefrontal dan subkortikal ataupun ada penurunan kolinergik dan peningkatan aktivitas dopaminergik, pada saat kadar serotonin dan kadar GABA (Gamma-Aminobutyric Acid) bermakna. Hasil studi didapatkan bahwa pasien dengan penurunan fungsi kognitif terjadi pada $24 \%-34 \%$ pasien. Penurunan fungsi kognitif tersebut mirip dengan gejala traumatic brain injury (34\%) dan pasien mirip dengan Alzheimer's disease dan delirium (24\%). (Cartwright, 2012; Iwashyna et al., 2012; Needham, 2012; Davidson et al., 2013; Pandharipande et al., 2013; JC et al., 2014; T. J. Iwashyna, 2014; Sottile, Peter, Amy Nordon-Craft, Daniel Malone, Darcie M. Luby, Margaret Schenkman, 2015)

Penyebabnya diantaranya riwayat menggunakan ventilator mekanik (33\%), infeksi atau sepsis $(50 \%)$, pasien mendapatkan perawatan 2 hari sampai dengan $>1$ minggu di ICU $(>50 \%)$, delirium dan berbagai penyakit kritis atau sepsis $(70 \%)$, Penyakit jantung koroner (PJK) (36,6\%), PJK Unstable Angina (UA) (41,5\%), Hipertensi (19,5\%), Supraventikular Takikardi (SVT) $(2,4 \%)$, tanda dan gejala tardive dyskenesia (Davidson et al., 2013; T. J. Iwashyna, 2014; Hoffman and Guttendorf, 2015; Suwardianto, 2016). Faktor penyebab utama yaitu perawatan lama ( $\geq 2$ hari) dan mobilisasi minimal. Faktor penyebab lainnya yaitu riwayat kesehatan sebelumnya (status kesehatan dan riwayat 
penyakit sebelumya), penyakit akut, penyakit kritis (delirium, hipoksia, hipotensi, disregulasi glukosa, gagal napas, shock, CHF (Congestive Heart Failure), sepsis dan lainnya), tingkat keparahan penyakit, peradangan, kehilangan kekuatan otot, sedasi, dan tingkat kecemasan (ketidakpuasan komunikasi, gangguan tidur) (Needham, 2012; Needham et al., 2012; Hopkins, 2013; JC et al., 2014; T. Iwashyna, 2014). Jika penurunan fungsi fisik dan kognitif tidak segera dicegah di ICU maka masalah tersebut akan muncul dan berdampak pada kesehatan pasien post ICU.

Dampak dari penurunan fungsi fisik berupa penurunan motor (motor activity) akan memperburuk dan melemahkan fungsi organ yang lain jika tidak segera dicegah dalam perawatannya di ICU (Nathan E, Brummel, James C. Jackson, 2013) Dampak penurunan fungsi fisik pasien ICU dan setelah keluar dari ICU yaitu bertambah lamanya waktu perawatan, penurunan fungsi kognitif, fungsi fisik (organ, kontraktilitas otot, kapasitas fungsi dan nyeri, vitalitas, kelelahan), dan memburuknya kesehatan mental (kecemasan), respon emosional, depresi, refleksi, kesendirian, ketidakmampuan melakukan aktivitas dan penggunakan instrumen dalam kehidupan sehari-hari. Fenomena penurunan fungsi fisik dan kognitif post ICU berdasarkan dampak tersebut menunjukkan penurunan kesehatan pasien terutama pada fungsi fisik, kognitif dan kesehatan mental berupa kecemasan, maka perlu strategi intervensi di ICU dalam pencegahannya. Pencegahan untuk meminimalkan kejadian penurunan fungsi fisik dan kognitif post ICU seharusnya mampu dilaksanakan sesuai dengan peran perawat kritis.

\section{METHOD}

Desain penelitian ini adalah desain crosssectional. Populasi adalah semua pasien kritis di Instalasi Perawatan Intensif RS Baptis Kediri. Besar Sample adalah 41 responden sesuai dengan kriteria inklusi yaitu pasien yang mendapat perawatan 24 jam pertama di Instalasi Perawatan Intensif. Sample dengan menggunakan total sampling. Variabel independen penelitian adalah pemberian sedasi, dan variabel dependen adalah Tardive Dyskinesia, dan Motor Activity, Data dikumpulkan menggunakan Checklist tanda gejala tardive dyskenesia dan Motor Activity Assessment. Penelitian dilakukan selama 1 bulan pada bulan Juli 2017. Cara pengambilan data dengan cara pengukuran secara langsung kepada pasien dan observasi respon pasien.

\section{RESULT}

Peneliti mendapatkan hasil penelitian yaitu data umum pasien kritis, cardiac workload, Sedation Scale for Critically ill, Physical Function-Tardive Dyskenesia.

Tabel 1. Karekteristik Data Umum pada pasien kritis di Instalasi Perawatan Intensif RS Baptis Kediri $(n=41)$

\begin{tabular}{lcc}
\hline Karakteristik & Jumlah & $\begin{array}{c}\text { Persentase } \\
(\mathbf{\%})\end{array}$ \\
\hline Jenis Kelamin & & \\
\hline Laki-laki & 15 & 36,6 \\
\hline Perempuan & 26 & 63,4 \\
\hline Umur & & \\
\hline$<35$ & 1 & 2,4 \\
\hline $35-39$ Tahun & 1 & 2,4 \\
\hline 40-44 Tahun & 4 & 9,8 \\
\hline 45-49 Tahun & 7 & 17,1 \\
\hline 50-54 Tahun & 3 & 7,3 \\
\hline$>55$ Tahun & 25 & 61,0 \\
\hline Sedasi & & \\
\hline $\begin{array}{l}\text { Morphine 2,5 } \\
\text { mg IV prn }\end{array}$ & 41 & 100 \\
\hline
\end{tabular}

Tabel 1 menunjukkan bahwa paling banyak responden berjenis kelamin lakilaki yaitu berjumlah 26 responden $(63,4 \%)$. Responden paling banyak berumur > 55 tahun yaitu berjumlah 25 responden (61,0\%). Responden paling banyak memiliki diagnosa PJK UA (unstable angina) yaitu sejumlah 17 
responden (41,5\%). Semua responden mendapatkan sedasi morphine 2,5 mg IV prn. Data demografi pada pasien kritis yang dirawat di Instalasi Perawatan Intensif paling banyak adalah perempuan dengan usia > 55 tahun hal ini dimungkinkan dikarenakan setelah 55 atau 60 tahun (menopausal stage) hipertensi lebih banyak ditemukan pada perempuan (kehilangan hormon estrogen yang bersifat mencegah hipertensi) dari pada laki-laki. Responden dilakukan pengkajian 24 jam pertama masuk instalasi perawatan intensif dan telah dipasang monitor jantung dan Oksimetri untuk mengukur saturasi oksigen, setelah itu dilakukan identifikasi jenis kelamin, umur, diagnosa medis, dan saat pasien kritis terjadi kegelisahan dan menunjukkan perilaku no cooperative perawat memberikan morphine $2,5 \mathrm{mg}$ IV.

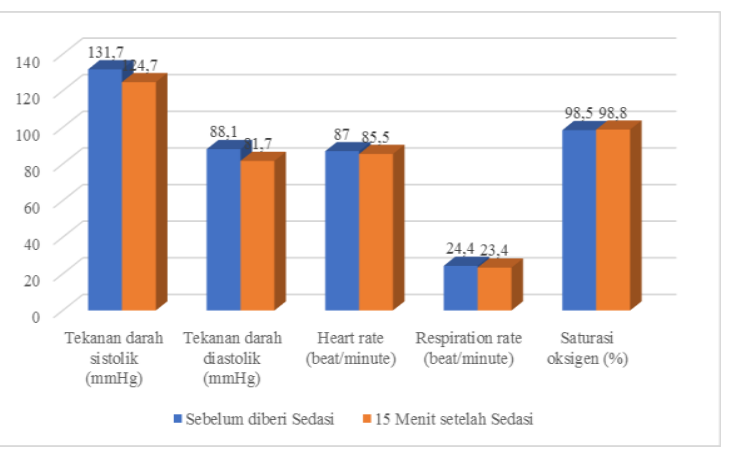

Gambar 1. Karakteristik Cardiac Workload pada Pasien Kritis di Instalasi Perawatan Intensif RS Baptis Kediri $(n=41)$

Berdasarkan Gambar 1 menunjukan bahwa terjadi penurunan tekanan darah sistolik (TDS) $(7,0 \mathrm{mmHg})$, tekanan darah diastolik (TDD) $(6,4 \mathrm{mmHg})$, Heat rate (1,5 kali/menit), Respiration rate $(0,5$ kali/menit). Terjadi peningkatan saturasi oksigen sebeesar 0,2 \%. Data tersebut menunjukkan tekanan darah sistolik sebelum diberikan sedasi morphine 2,5 mg memiliki mean $131,7 \mathrm{mmHg}$ dan 15 menit setelah pemberian sedasi terjadi penurunan $7,0 \mathrm{mmHg}$ dengan mean tekanan darah sistolik 124,7 $\mathrm{mmHg}$.
Tekanan darah diastolik sebelum diberikan sedasi morphine 2,5 $\mathrm{mg}$ memiliki mean 88,1 mmHg dan 15 menit setelah pemberian sedasi terjadi penurunan $6,4 \mathrm{mmHg}$ dengan mean tekanan darah diastolik 81,7 mmHg. Heart rate sebelum diberikan sedasi morphine 2,5 mg memiliki mean 87,0 kali/menit dan 15 menit setelah pemberian sedasi terjadi penurunan heart rate 1,5 kali permenit dengan mean 85,5 kali per menit. Respiration rate sebelum diberikan sedasi morphine $2,5 \mathrm{mg}$ memiliki mean 24,4 kali/menit (Takipnea) dan 15 menit setelah pemberian sedasi terjadi penurunan 0,5 kali permenit dengan mean Respiration rate 23,4 kali per menit (Takipnea). Saturasi oksigen sebelum diberikan sedasi morphine 2,5 $\mathrm{mg}$ memiliki mean 98,5 \% dan 15 menit setelah pemberian sedasi terjadi peningkatan $0,3 \%$ dengan mean saturasi oksigen 98,8 \%. Pasien PJK yang dirawat di Instalasi Perawatan Intensif dilakukan observasi secara keseluruhan dengan menggunakan monitor jantung yang telah ter setting pada pasien.

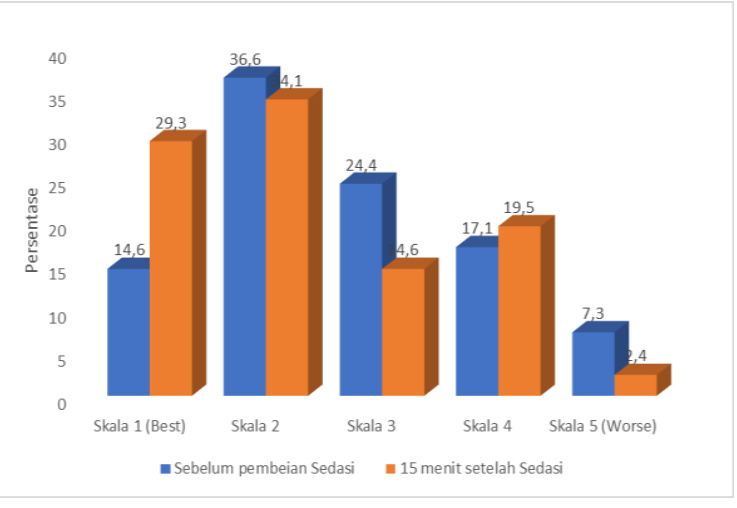

Gambar 2. Karekteristik Sedation Scale for Critically Ill Patients pada pasien

Kritis di Instalasi Perawatan Intensif RS Baptis Kediri $(n=41)$

Berdasarkan Gambar 2 didapatkan bahwa Sedation Scale for Critically Ill Patients sebelum dan sesudah pasien mendapatkan sedasi berada pada skala 2 $(36,6 \%$ ke $34,4 \%)$. 


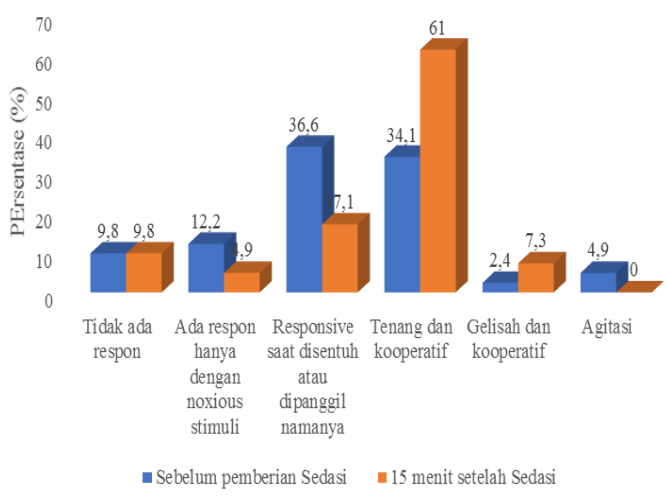

Gambar 3. Physical Function pada pasien Kritis di Instalasi Perawatan Intensif RS Baptis Kediri $(n=41)$

Gambar 3 didapatkan bahwa penurunan fungsi fisik dengan didapatkan

Tabel 4. Tardive Dyskinesia pada pasien Kritis di Instalasi Perawatan Intensif RS Baptis Kediri ( $\mathrm{n}=41)$

\begin{tabular}{|c|c|c|c|c|c|}
\hline \multirow[t]{2}{*}{ Indikator } & \multicolumn{2}{|c|}{ Sebelum } & \multicolumn{2}{|c|}{ Sesudah } & $-/+$ \\
\hline & $\sum$ & $\%$ & $\sum$ & $\%$ & $\%$ \\
\hline Tidak ada tanda Tardive Dyskinesia & 26 & 63,4 & 30 & 73,1 & 9,7 \\
\hline $\begin{array}{l}\text { Memiliki tanda dan Gejala Tardive } \\
\text { Dyskinesia }\end{array}$ & 15 & 36,6 & 11 & 26,9 & $-9,7$ \\
\hline - Repetition grimacing & 5 & 12,2 & 3 & 7,3 & $-4,9$ \\
\hline - Tongue Protrusion & 1 & 2,4 & 3 & 7,3 & 4,9 \\
\hline - Lip smacking, puckering, and pursing & 0 & 0 & 1 & 2,4 & 2,4 \\
\hline - $\quad$ Rapid eye blinking & 1 & 2,4 & 1 & 2,4 & 0 \\
\hline - Rapid movements of the arms and legs & 11 & 26,8 & 7 & 17,1 & $-9,7$ \\
\hline
\end{tabular}

Keterangan: *) Pasien dapat menunjukkan lebih dari satu tanda pada indikator Tardive Dyskinesia atau bahkan tidak sama sekali. Tanda (-) adalah penurunan nilai.

Karakteristik penurunan fungsi fisik pasien dengan pendekatan pengenalan tanda dan gejala Tardive Dyskinesia pada pasien PJK sebelum diberikan sedasi memperlihatkan 5 tanda dari Tardive Dyskinesia sedangkan 15 menit setelah pemberian sedasi morphine 2,5 mg IV memperlihatkan bahwa semua tanda Tardive Dyskinesia muncul, walaupun terjadi peningkatan responden yang tidak menunjukkan tanda Tardive Dyskinesia dari 26 responden mejadi 30 responden. Pasien menunjukkan repetition grimacing, Lip smacking, puckering, and pursing, dan Rapid movements of the arms and legs. Hal tersebut merupakan respon dari ketidaknyamanan yang bahwa sebelum diberikan sedasi paling banyak pasien responsive saat disentuh atau dipanggil namannya yaitu sebanyak 15 responden $(36,6 \%)$ dan sesudah pemberian sedasi paling banyak pasien kritis tenang dan kooperatif sebanyak 25 responden $(61,0 \%)$. Pasien kritis memiliki penurunan fungsi kognitif dengan memperlihatkan pasien mengalami gelisah hingga agitatif. Physical Function terjadi penuruan berupa motor activity setelah pemberian sedasi pada kondisi yaitu ada respon dengan noxious stimuli $(7,3 \%)$, responsive saat disentuh atau dipanggil namanya $(19,5 \%)$ dan peningkaan skor agitasi dan koperatif $(4,9 \%)$. 
Tabel 5. Analisis Variabel terhadap pemberian Sedasi pada pasien Kritis di Instalasi Perawatan Intensif RS Baptis Kediri $(n=41)$

\begin{tabular}{lc}
\hline \multicolumn{1}{c}{ Variabel } & $\begin{array}{c}\text { Independent T-Test } \\
(\boldsymbol{p})\end{array}$ \\
\hline Tardive Dyskinesia & 0,317 \\
\hline Physical Function & $\mathbf{0 , 0 0 5}$ \\
\hline
\end{tabular}

Tabel 5 didapatkan bahwa pemberian sedasi pada pasien ICU 24 jam pertama mempengaruhi fungsi fisik pasien kritis dibuktikan terdapat pengaruh pada Physical Function pada pasien kritis $(\mathrm{p}=0,005)$.

\section{PEMBAHASAN}

Berdasarkan hasil penelitian didapatkan bahwa pemberian sedasi tidak mempengaruhi perubahan indikator fungsi fisik berupa Tardive Dyskenesia $(0,317)$. Karakteristik fungsi fisik pada kondisi Tardive Dyskinesia pada pasien kritis sebelum dan setelah pemberian sedasi memperlihatkan bahwa pasien menunjukkan perilaku repetiting grimacing, Lip smacking, puckering, and pursing, Rapid movements of the arms and legs. Hal tersebut merupakan respon dari ketidaknyamanan yang diinterprestasikan melalui saraf pusat bermielin. Penurunan fungsi fisik berupa Tardive Dyskinesia merupakan sindrom neorologik yang berasosiasi dengan prolog penggunaan obat neuroleptic. Karakteristik Tardive Dyskenesia yaitu pergerakan wajah berulang (repetitive), pergerakan yang tidak terkontrol (involuntary), pergerakan yang tidak disengaja. Tardive dyskinesia merupakan temuan oleh berhentinya akhiran pengobatan. Walaupun gejala mungkin ada selama dan setelah pemberian pengobatan dihentikan. Tardive Dyskinesia diantaranya repetiting grimacing, Tonggue Protrusion), Lip smacking, puckering, and pursing, rapid eye blinking, Rapid movements of the arms and legs. Hasil penelitian menunjukan bahwa tidak adanya perubahan yang signifikan dimungkinkan bahwa responden masih berespon pada asosiasi neuroleptic dan beberapa responden masih mendapatkan titrasi sedasi kuat (Morphine). Tardive Dyskinesia yang muncul pada pasien dimungkinkan karena perubahan secara cepat neorologik bermielin dikarenakan perubahan dosis sedasi atau penghentian sedasi.

Berdasarkan hasil penelitian didapatkan bahwa pemberian sedasi mempengaruhi secara signifikan terhadap Physical Function $(\mathrm{p}=0,005)$ dan didalamnya memperlihatkan kondisi penurunan fungsi fisik dan kognitif berupa agitasi. Berdasarkan hasil penelitian didapatkan bahwa Physical Function sebelum diberikan sedasi paling banyak pasien responsive saat disentuh atau dipanggil namanya yaitu sebanyak 15 responden (36,6\%). Physical Function sesudah pemberian sedasi paling banyak pasien kritis tenang dan kooperatif sebanyak 25 responden $(61,0 \%)$. Physical Function yang digambarkan adanya penurunan fungsi fisik dan kognitif dimungkinkan pada pasien yang mendapatkan sedasi dan mengarah pada keadaan agitasi pasien dapat didiskripsikan menjadi tidak berespon yaitu tidak dapat berpindah atau bergerak dengan noxious stimulus (suctioning, respon nyeri pada sternal), pasien dapat berespon hanya dengan noxious stimuli yaitu membuka mata, mengangkat alis, memutar kepala, pergerakan lengan dengan noxious stimuli. Responden juga dapat menunjukkan responsive saat disentuh atau dipanggil namanya yaitu membuka mata, menggangkat alis, memutar kepala, pergerakan lengan dengan sentuhan atau memanggil nama dengan suara keras. Pasien diharapkan berada pada respon tenang dan kooperatif yaitu tidak ada stimulus eksternal yang terjadi untuk terjadinya pergerakan dan pasien dapat menyesuaikan gerakan dan mengikuti perintah. Pasien gelisah dan 
kooperatif memperlihatkan bahwa tidak ada stimulus eksternal yang terjadi untuk terjadinya pergerakan dan pasien dapat mengambil selimut atau gelas atau menyelimuti dirinya sendiri dan mengikuti perintah. Pasien dengan keadaan agitasi yaitu tidak ada stimulus eksternal yang terjadi untuk terjadinya perkerakan dan pasien berusaha untuk berdiri atau pergerakan lengan keluar dari tempat tidur dan tidak konsisten mengikuti perintah, dan kedaan pasien bisa dalam keadaan Agitasi berbahaya, tidak kooperatif dimana Tidak ada stimulus eksternal yang terjadi untuk terjadinya perkerakan dan pasien dan pasien menarik SL (Selang lambung) atau kateter urin atau mendera/menyerang petugas/mencoba untuk mengeluarkan lengan keluar dari tempat tidur dan tidak tenang ketika bertanya. Hasil penelitian didapatkan bahwa pemberian sedasi secara signifikan mempengaruhi Physical Function dimana respon sedasi berupa morphin 2,5 mg mampu menurunkan level motor pasien yang awalnya pasien agitasi mampu diturunkan sampai pada level koperatif. Peran perawat dengan mengetahui kondisi pasien sebelum dan setelah pemberian sedasi terjadi perubahan respon motor akibat relaksan, perawat harus mampu mengetahui keadaan-keadaan tersebut melalui indikator motor activity. Respon motor yang berlebihan mampu meningkatan beban jantung dan kegelisahan pada pasien namun pasien yang mampu mencapai relaksasi dengan atau tanpa sedasi akan meningatkan aktifitas parasimpatis dari nervus vagus (Suwardianto, 2013), hal tersebut mampu terjadi penurunan cardiac workload pada pasien kritis yang terjadi kegelisahan.

Berdasarkan hasil penelitian pemberian sedasi mempengaruhi Sedation Scale for Critically Ill Patients $(0,005)$. Hasil didapatkan bahwa Sedation Scale for Critically Ill Patients sebelum dan sesudah pasien mendapatkan sedasi berada pada skala $2(36,6 \%$ ke $34,4 \%)$.
Agitasi yang buruk dimana Pergerakan tubuh atau ketidakmauan dengan treatment/prosedur atau pembatasan pergerakan tubuh secara signifikan membahayakan pasien dan petugas. Sedation Scale for Critically Ill Patients merupakan alat pengkajian yang khusus digunakan oleh perawat dalam mengidentifikasi skala agitasi pada pasien kritis. Indikator dalam Sedation Scale for Critically Ill Patients yaitu Consciousness, agitasi, kecemasan, tidur, dan pasien dengan terpasang ventilator. Consciousness mengidentifikasikan bahwa pasien Bangun, sadar akan dirinya dan lingkungan (orientasi baik), Agitasi mengidentifikasikan bahwa pasien mengerakan badan pasien/keselamatan pasien, Kegaduhan pasien, dan laporan pasien. Indikator kecemasan yaitu perawat melihat kecemasan pasien (Faces Anxiety). Indikator tidur yaitu perawat mengobservasi tidur dan kualitas tidur yang dirasakan pasien. Indikator pasien dengan terpasang ventilator dimana perawat Pola pernapasan relative pada ventilator. Hasil penelitian memperlihatkan bahwa terjadi perubahan skala agitasi yang signifikan hal ini menunjukkan bahwa agitasi menurun seiring pemberian sedasi. Skala agitasi semakin buruk maka semakin buruk kondisi pasien untuk tenang dan koperatif juga berpengaruh pada kondisi respon pasien dalam penyembuhan di area keperawatan. Pasien setelah diberikan sedasi morphin 2,5 mg IV paling banyak responden berada pada level 2 sebelum dan setelah responden. Semakin membaiknya dan koperatifnya pasien maka pasien akan mampu memperlihatkan konsisi yang baik.

Berdasarkan hasil penelitian didapatkan bahwa didapatkan bahwa terjadi penurunan pada tekanan darah sistolik (TDS) $(7,0 \mathrm{mmHg}$, tekanan darah diastolik (TDD) $(6,4 \mathrm{mmHg}$, Heat rate (1,5 kali/menit), Respiration rate $(0,5$ kali/menit). Terjadi peningkatan saturasi oksigen sebesar $0,2 \%$. Pasien kritis 
dengan Penyakit Jantung Koroner (PJK) merupakan kondisi penyakit dimana pembuluh darah yang menyuplai makanan dan oksigen untuk otot jantung mengalami sumbatan. Sumbatan paling sering akibat oleh penumpukan kolesterol di dinding pembuluh darah coroner (Kurniadi, 2013). Kombinasi hipoksia, penurunan ketersediaan energi, dan asidosis dengan cepat akan merusak fungsi ventrikel kiri. Kerusakan kontraksi pada bagian otot jantung yang terkena akan menurun karena serabut otot tidak cukup memendek sehingga kekuatan serta percepatan aliran yang dihasilkan berkurang. Lebih lanjut, pada dinding ventrikel terjadi gerakan yang abnormal di daerah iskemia sehingga darah yang diedarkan pada tiap kontraksi akan berkurang. Pemulihan aliran darah melalui arteri koronaria akan mengembalikan metabolisme aerob yang normal dan kontraktilitas jantung. Akan tetapi, bila aliran darah tidak dapat dipulihkan, maka terjadi infark miokard. Hasil penelitian didapatkan bahwa terjadi perubahan selisih sebelum dan sesudah diberikan sedasi pada cardiac workload yaitu TDS terjadi penurunan $7,0 \mathrm{mmHg}$, TDD terjadi penurunan $6,4 \mathrm{mmHg}, \mathrm{HR}$ terjadi penurunan $1,5 \mathrm{kali} / \mathrm{menit}, \mathrm{RR}$ terjadi penurunan $0,5 \mathrm{kali} / \mathrm{menit}$, dan terjadi peningkatan $0,2 \%$ saturasi oksigen pada pasien kritis. Peran perawat dalam mengidentifikasi gambaran cardiac workload perlu ditingkatkan dan perlunya suatu kolaborasi tindakan keperawatan sehingga mampu meningkatkan perbaikan cardiac workload. Cardiac workload yang diidentifikasi yaitu tekanan darah, HR, $\mathrm{RR}, \mathrm{SaO} 2$ semua mengalami perubahan dari kondisi awal sebelum diberikan sedasi. Pemberian sedasi untuk dapat memberikan efek tenang dimungkinkan menyebabkan terjadi perubahan nilai cardiac workload setelah 15 menit setelah pemberian sedasi berupa morphin 2,5 ml. Pemberian sedasi mampu meningkatkan respon parasimpatis untuk berespon pada cardiac workload, sehingga perawat harus mampu memonitoring perubahan-perubahan yang bermakna setelah pemberian sedasi. Peran perawat menjadi sangat penting dalam mengidentifikasi dan melaksanakan tindakan mandiri dalam hasil identifikasi kecemasan bukan menguatkan efek dari pemberian sedasi saja tapi harus mampu mendukung pasien dalam menurunkan kecemasan, agitasi, ataupun nyeri dengan memberikan intervensi mandiri, modifikasi lingkungan. Perawat kritis diharapankan mampu menerapkan tatakelola efektif (transformasi) dengan mengembangkan diri dalam komunikasi, berfikir kritis dan mampu mengubah lingkungan (Suwardianto, 2015), sehingga asuhan keperawatan pada pasien kritis mampu memiliki gold standar dalam menentapkan kualitas asuhan keperawatan pada pasien.

\section{KESIMPULAN DAN SARAN Kesimpulan}

Peran perawat kritis yaitu melaksanakan intervensi keperawatan secara mandiri maupun kolaboratif komprehensif untuk pencegahan munculnya masalah penurunan fungsi fisik dan kognitif post ICU yang dapat terjadi setelah pasien keluar dari ICU. Beberapa intervensi yang dapat dilakukan untuk mencegah salah satu atau beberapa masalah penurunan fungsi fisik dan kognitif berdasakan Evidence Base Practice yaitu physical therapy, cognitive therapy, early activity, early physical therapy, exercise training, latihan fisik dini, dan rehabilitasi fisik. Hasil penelitian pada intervensi tersebut hanya mengukur efektivitas salah satu gangguan fungsi fisik, kognitif dalam jangka waktu yang lama dan saat pasien pulang dari rumah sakit. Seperti hasil penelitian intervensi early activity yaitu intervensi tersebut hanya mengukur peningkatan fungsi fisik saja pada pasien post ICU. Hasil penelitian intervensi cognitive 
therapy pada pasien kritis di ICU hanya mengukur mengukur peningkatan fungsi fisik saja pada pasien post ICU sehingga masalah yang lain akan tetap muncul.

\section{Saran}

Perawat kritis dan gawat darurat diharapkan mampu mengidentifikasi gambaran penurunan fungsi fisik dan kognitif di ICU sehingga mampu meningkatkan kualitas pelayanan dan kualitas hidup pasien setelah keluar dari ICU. Penerapan Evidence Base Practice pada tempat pelayanan sangatlah penting dan harus dilakukan sedini mungkin untuk mencegah permasalahanpermasalahan yang dapat terjadi setelah pasien keluar dari ICU. Perawat perlu mengembangkan Clinical Pathway keperawatan pasien Kritis di Instalasi Perawatan Intensif untuk memonitoring dan mengevaluasi perkembangan pasien sehingga Gold Standar dalam pencapaian Outcame keperawatan tercapai secara optimal

\section{DAFTAR PUSTAKA}

AACN (2016) 'About critical care nursing', American Association of Critical-Care Nurses, p. 1. Available at: http://www.aacn.org/wd/publishin $\mathrm{g} /$ content/pressroom/aboutcritical carenursing.pcms?menu= (Accessed: 29 August 2016).

Abelha, F. J., Santos, C. C., Maia, P. C., Castro, M. A. and Barros, $\mathrm{H}$. (2007) 'Quality of life after stay in surgical intensive care unit', BMC Anesthesiology, 7(8), pp. 112. doi: 10.1186/1471-2253/7/8.

Alan. (2014). Heart Disease and Stroke Statistics.

http://circ.ahajournals.org/content. American Heart Associaton.
Diakses 4 Februari 2014, jam $18.00 \mathrm{WIB}$

Bangun. (2005). Terapi Jus Dan Ramuan Tradisional Untuk Kolesterol. Depok: Agromedia Pustaka

Boestan, Iwan N, Rurus Suryawan. (2003). Ilmu Penyakit Jantung. Surabaya: Airlangga University Press

Bonita A, G. (2009) 'Home cardiac rehabilitation for congestive heart failure: a nursing case management approach', Rehabilitation Nursing, 24(4), pp. 143-147.

Cartwright, M. M. (2012) The high incidence of post intensive care unit (ICU) anxiety and depression, Psychology Today. Available at: https://www.psychologytoday.co $\mathrm{m} / \mathrm{blog} /$ food-thought/201202/thehigh-incidence-post-intensivecare-unit-icu-anxiety-anddepression (Accessed: 9 September 2016).

Davidson, Christopher. (2003). Penyakit Jantung Koroner. Jakarta: Dian Rakyat

Davidson, J. E., Hopkins, R. O., Louis, D. and Iwarshyna, T. (2013) 'Post-intensive care syndrome', Society of Critical Care Medicine, 1(1), pp. 1-4.

Gardner, Samuel. (2007). Smart Treatment For High Blood Pre Panduan Sehat Mengatasi Tekanan Darah Tinggi. Jakarta: Prestasi Pustakaraya

Garland, K, O., CD, R., M, Y. and R, F. (2013) 'Epidemiology of critically ill patients in intensive care units: a population-base observational study', Critical Care, 17(5), p. 212. doi: $10.1186 / \mathrm{cc} 13026$.

Glance. (2015). Heart Disease and Stroke Statistics. American Heart Association-BBB

Hidayat, Alimul, Aziz. (2012). Riset Keperawatan dan Teknik 
Penulisan Ilmiah. Jakarta: Salemba Medika

Hoffman, L. A. and Guttendorf, J. (2015) Post Intensive care syndrome: risk factors and prevention strategies, AHC media. Available at: https://www.ahcmedia.com/article s/134820-post-intensive-caresyndrome-risk-factors-andprevention-strategies (Accessed: 1 January 2016).

Hopkins, R. O. (2013) 'Strategies to ensure long-term quality of life in ICU survivors', Society of Critical Care Medicine, 1(1), p. 1.

Ireland (2011) National standards for adult critical care services. Ireland: Joint Faculty of Intensive Care Medicine of Ireland (JFCMI) in association with The Intensive Care Society of Ireland (ICSI).

Irmalia, (2015). Pedoman Tatalaksana Sindrom Koroner Akut Edisi ketiga. Jakarta. Perhimpunan dokter spesialis kardiovaskuler Indonesia (PP PERKI).

Iwang, Prasetya W, Ismail. (2006). Antitrombolik dan Trombolitik pada penyakit Jantung Koroner. Jakarta: Fakultas Kedokteran Universitas Indonesia

Iwashyna, T. (2014) 'What you need to know about post-intensive care syndrome (PICS)', Health System-University of Michigan, 1(1), pp. 1-3.

Iwashyna, T. J. (2014) 'Post-intensive care syndrome: improving the future of icu patients', 24nd Critical Care Congress Review, 1(1), pp. 13-16.

Iwashyna, T. J., Cooke, C. R., Wunsch, H. and Kahm, J. M. (2012) 'Population burden of long-term survivorship after severe sepsis in older americans', Journal compilation (C) 2012, The American Geriatrics Society, 60(6), pp. 1070-1077.
JC, J., PP, P., TD, G., NE, B. and JL, T. (2014) 'Depression, posttraumatic stress disorder, and functional disability in survivors of critical illness in the brain-icu study: a longitudinal cohort study', The Lancet Respiratory Medicine, 2(5), pp. 369-379.

Kabo, Peter, (2008). Mengungkap Pengobatan Penyakit Jantung koroner. Jakarta: PT Gramedia Pustaka Utama

Kasron, 2012. Pencegahan serta Pengobatan. Yogyakarta: Nuha Medika

Kementrian Kesehatan RI. (2013). Riset Kesehatah Dasar Riskesdas 2013. Badan Penelitian dan Pengembangan Kesehatan, Jakarta; 2013. Hal 90-93

Kowalak, Jeninifer P. (2011), Buku Ajar Patofisiologi. Jakarta: EGC

Kurniadi, Helmanu. (2013). Stop Gejala Penyakit Jantung Koroner. Yogyakarta: Familia

Mansjoer, Arif. (2008). Kapita Selekta Kedokteran Edisi Ketiga. Jakarta: Media Aesculapius, hal: 518-519

Mawi, Martiem. (2003). Indeks Masa Tubuh Sebagai Determinan Penyakit Jantung Koroner pada Orang Dewasa Berusia di Atas 35 tahun. Jurnal Kedokteran Trisakti. Vol 23. No 3

Muchtar, Zahra. (2010). Gambaran Epidemiologi Penyakit Jantung Koroner pada Pasien Wanita di Rumah Sakit Harapan Kita Jakarta Tahun 2009. Skripsi, Universitas Indonesia

Muttaqin, Arif. (2009). Buku Ajar Asuhan Keperawatan dengan Gangguan Sistem Kardiovaskuler dan Hematologi. Jakarta: Salemba Medika

Nadesul, Hendrawan. (2009). Cerdas Menaklukkan Semua Penyakit Orang Sekarang. Jakarta: Kompas Media Nusantara 
Nastiti, Amadea K. (2012). Klasifikasi Kadar Gula Dalam Darah. http://amadeanastitifst09.web.unair.ac.id/. Diakses 27 Pebruari 2014, jam 22.00 WIB

Nathan E, Brummel, James C. Jackson, T. D. G. (2013) 'A combined early cognititive and physical rehabilitation program for people who are critically Iil: The activity and cognitive therapy in the intensive care unit (ACT-ICU) trial', Physical Therapy Critical Illness, 92(12), pp. 1580-1592.

Needham, D. M. (2012) 'Improving longterm outcomes after discharge from intensive care unit: Report from a stakeholders' conference', Critical Care Medicine, 40(2), pp. 502-509.

Needham, D. M., Davidson, J., Cohan, H., PharmD and Hopkins, R. (2012) 'Improving long-term outcomes after discharge from intensive care unit: report from a stakeholders' conference', the Society of Critical Care Medicine and Lippincott Williams \& Wilkins, 40(2), pp. 502-509.

Pandharipande, P., Girard, T., Morandi, A. and Thompsom, J. (2013) 'Long-term cognitive impairment after critical illness', The New England Journal Medicine, 369(14), pp. 1306-1316. doi: 10.1056/NEJMoa1301373.

Pradana, Wisnu, Mahardika. (2011). Peran Enhanced External Counterplussation pada Penyakit Jantung Koroner. Artikel Khusus, Universitas Katolik Atma jaya, Jakarta. Vol 61 No10. Oktober 2011. Hal: 2

Pudiastuti, Ratna, Dewi. (2013). Penyakit-Penyakit Mematikan. Yogyakarta: Nuha Medika

Pusfitasari, Intan. (2013). Hubungan Dukungan Sosial Keluarga dengan Tingkat Kecemasan Pasien Penyakit Jantung Koroner.
STIKES RS. BAPTIS Kediri. Hal: 37

Rocmayanti. (2011). Analisis Faktor yang Mempengaruhi Kualitas Hidup Pasien Penyakit Jantung Koroner di Rumah Sakit Pelni Jakarta. Tesis Univesitas Indonesia Fakultas Ilmu Keperawatan. Hal 70

Setiadi. (2007). Konsep \& Penulisan Riset Keperawatan. Yogyakarta: Graha Ilmu

Silvia, A. Prince, Lorraine, M. Wilson. (2005). Patofisiologis Klinis Proses-Proses Penyakit. Edisi 6. Vol 1. Jakarta: ECG

Sottile, Peter, Amy Nordon-Craft, Daniel Malone, Darcie M. Luby, Margaret Schenkman, M. M. (2015) 'Physical therapis treatment of patients in the neurogical intensive care unit: description of practice', Physical Therapy, 95(7), pp. 1006-1014.

Strahan, E. H. . and Brown, R. J. (2005) 'A quantitative study of the experiences of patients following transfer from intensive care', Intensive and Critical NursingICCN, 21(21), pp. 160-171.

Sugiyono. (2009). Metode Penelitian Kuantitatif, Kualitatif dan $R \& D$, Bandung: Alfabeta

Supriono, Mamat. (2008). Faktor-Faktor Resiko yang Berpengaruh Terhadap Kejadian Penyakit jantung Koroner pada Kelompok Usia $\leq 45$ Tahun. Tesis, Study Kasus di RSUP Dr. Kariadi dan RS Telogorejo, Semarang. Hal: 53-58

Suwardianto, H. (2016) 'Tardive dyskenesia, motor activity, sedation scale, and cardiac workload in baptis kediri hospital', Tardive Dyskenesia, Motor Activity, Sedation Scale, Dan Cardiac Workload, 4(1), p. 1.

Suwardianto, Heru. (2013). Deep Breathing Relaxation As Therapy 
To Decrease Blood Preassure On

Hypertension Patients. In Proceedings Faculty Of Nursing Of Airlangga The fourd Internasional Nursing Conference Improving Quality Of Nursing Care Though Nursing Research and Innovations.

Suwardianto, Heru. (2015). Tantangan Profesi Keperawatan Dalam Efektifitas Tata Kelola Ketenagaan Di Rumah Sakit. Jakarta. Jawa Pos Indonesia. 27 Desember 2015.

Suwardianto. (2014). The Effectiveness of Deep Breathing and Slow Stroke Back Massage to Decrease the Blood Pressure on A Patient with Hypertension. Journal "Moving Forward Improving Nursing Education" Indonesian Nursing Journal of Education and Clinic (INJEC). Volume 1, Nomor 1, April 2014

Syamsudin. (2011). Buku Ajar Farmakoterapi Kardiovaskuler dan Renal. Jakarta: Salemba medika

Thomas L, Schwenk. (2003). New Hypertension Guidelines: JNC 7. http://www.jwatch.org/. NEJM Journal Watch. Diakses 20 Februari 2016, Jam 22.30 WIB

Udjianti, Wajan Juni. (2010). Keperawatan Kardiovaskular. Jakarta: Salemba Medika, hal: 107-114

Utami, Prapti. (2009). Solusi Sehat Mengatasi Penyakit Jantung Koroner. Jakarta: Agromedia Pustaka

Yatim, Faisal. (2005). Waspadai Jantung Koroner, Stoke, Meninggal Mendadak Atasi dengan Pola Hidup Sehat. Jakarta: Pustaka Populer Obor 